\title{
Preliminary phytochemical and physicochemical investigation of Woodfordia fruticosa (linn) kurz root
}

\author{
Vandana Janghel ${ }^{1}$, Saket Singh Chandel ${ }^{1}$, T. Venkatachalam ${ }^{2}$, \\ Sheetlesh Kumar', Kavi Bhushan Singh Chouhan ${ }^{3}$, Pushpendra Kumar Patel ${ }^{1}$
}

${ }^{1}$ Department of Pharmacognosy, Siddhi Vinayaka Institute of Technology and Sciences, Bilaspur, Chhattisgarh 495001, India, ${ }^{2}$ Department of Pharmaceutical Chemistry, JKKMMRF College of Pharmacy, Namakkal - 638 183, Tamil Nadu, India, ${ }^{3}$ Department of Pharmacognosy, Institute of Pharmaceutical Sciences, Guru Ghasidas Central University, Bilaspur, Chhattisgarh, 495004, India

\begin{abstract}
Introduction: The objective is to investigate the preliminary phytochemical and physicochemical properties of Woodfordia fruticosa Kurz roots. W. fruticosa, commonly called as Dhavi, is a large beautiful tree, about $10 \mathrm{ft}$ long, belongs to the family Lythraceae. These studies were performed because, before any experimental and clinical trial, phytoconstituents present in the plant should be known. Material and Methods: The root of W. Fruticosa contains protein, fixed oil, glycoside, carbohydrate, terpenoid, steroid, tannin, and saponin. The physiochemical analysis of $W$. fruticosaroot was also performed which includes ash value, loss on drying and extractive value determination. Result and Discussion: Total ash value, acid-insoluble ash, and water-soluble ash value were 6.5 $\% \mathrm{w} / \mathrm{w}, 2 \% \mathrm{w} / \mathrm{w}$, and $0.5 \% \mathrm{w} / \mathrm{w}$. Loss on drying was $4.4 \% \mathrm{w} / \mathrm{w}$, and extractive value was $3.4 \% \mathrm{w} / \mathrm{v}$ in water and $6.4 \% \mathrm{w} / \mathrm{v}$ in ethanol. Conclusion: This study revealed that these parameters will be useful in the identification and quality control of the genuine plant material or crude drug.
\end{abstract}

Key words: Glycosides, Physicochemical, Phytochemical, Woodfordia fruticosa

\section{INTRODUCTION}

$\mathrm{M}$ any researchers and scientist are on the verge of discovering of natural products exploiting natural products are the most consistently successful source of drug leads. More than half of drug molecules are natural derived compounds. It provides more structural and therapeutically diversity than synthetic products. There are so many natural products which have to be discovered, but the main challenge is to right access on this chemical diversity which is useful in severe ailments such as cancer and diabetes heart diseases. For the treatment of various types of disease, medicinal plants have been used from the primitive times. Plants contain different types of an active constituent that can be used for the therapeutic purpose or as precursors for pharmaceutical synthesis. During recent times, herbal therapies have become more popular due to low cost more effectiveness, easy availability, and fewer side effects. ${ }^{[1]}$ As a result, global market demand for herbs and their products has increased tremendously in recent years. Therefore, quality control of herbal products for the purpose of efficacy and safety is essential. ${ }^{[2]}$ Authentication and development of standardization parameter are essential for any crude drug and their formulation. The World Health Organization (WHO) has prescribed a number of standardization parameter for the quality control of medicinal plant materials. Quality control is determined on the basis of identity, purity, content, chemical, physical, and/or biological properties, as well as by manufacturing process. ${ }^{[3]}$ Thus, in this research work attempt has been made for standardization of Woodfordia fruticosa root by investigating its physicochemical and qualitative phytochemical properties.

\section{Address for correspondence:}

Dr. Saket Singh Chandel, Department of

Pharmacology, Siddhi Vinayaka Institute of

Technology and Sciences, Bilaspur, Chhattisgarh 495001,

India. Phone: +91-9827181552.

E-mail: singhpharma@gmail.com

Received: 11-09-2018

Revised: 04-11-2018

Accepted: 19-11-2018 


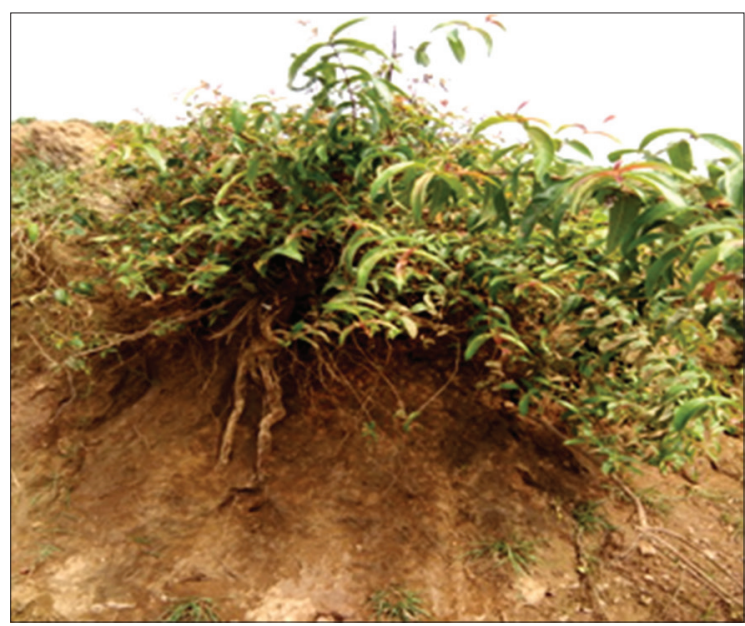

Figure 1: Woodfordia fruticosa

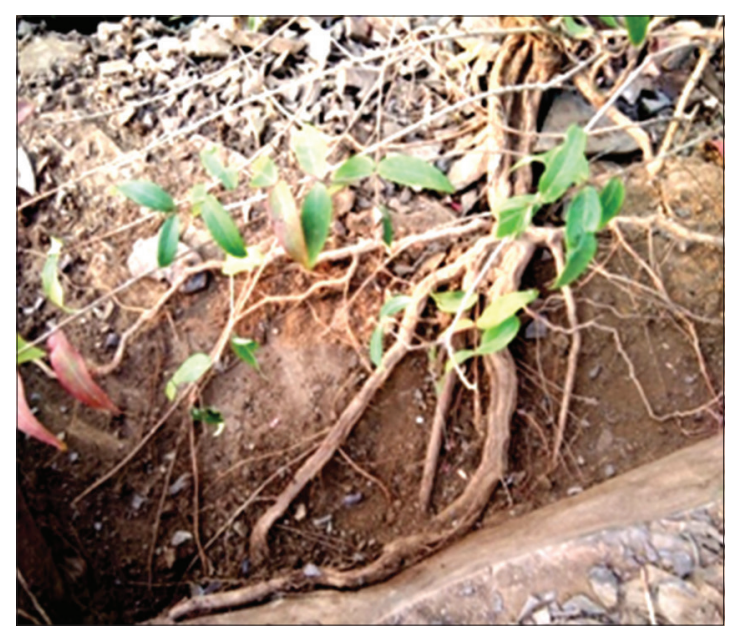

Figure 2: Woodfordia fruticosa root

W. fruticosa [Figures 1 and 2] commonly called as Dhavi, Dhavari, Dhatki, etc. It is a plant with medicinal properties and belongs to the family Lythraceae. The brown bark has fibers peeling off from the hairy stem. The stalkless, ovate, and lanceolate leaves are placed opposite to each other and sometimes in whorls of three arising at the nodes. It mainly grows in the hill region of India and also grows in the middle of India. The small, red, bell-shaped flowers arise from along the stems. The seeds are brown in color and flowers are brilliant red in color. Flowers of this plant are the most effective fermentation agents in Ayurvedic medicines. ${ }^{[4,5]}$

The flowers of $W$. fruticosa contain phenolic compounds, tannin, especially hydrolyzable tannins and flavonoids. The other phenolic constituents present in flower are steroids hecogenin and meso-inositol. Leaves of this plant contain triterpenoids lupeol which is triterpenoid in nature. Other constituents present in leaves are betulin, betulinic acid, oleanolic acid, and ursolic acid. Gallic acid is found to present in leaves and stems, ellagic acid in leaves and flowers and the new constituent norbergenin in stems, etc. ${ }^{[4]}$ The dried flowers of this plant are reported to be used for the treatment of hemorrhoids, dysentery, diarrhea, liver diseases, piles, mucous membranes related disorder, leukorrhoea, menorrhagia, ulcers, wounds, burning sensations, skin diseases, fever, herpes, etc. ${ }^{[5,6]}$

According to the literature survey, it was found that there is a lack of research on W. fruticosa (Linn.) Kurz root. Hence, the present study attempted to investigate preliminary phytochemical and physicochemical properties $W$. fruticosa (Linn.) Kurz root.

\section{Plant Material \\ Selection of Plant}

Woodfordia fruticosa was used traditionally in the rural areas from the long back for the different purposes like that prevention of uterine secretion after child birth. And there is lack of literature research on the root of Woodfordia fruticosa. Also the Literature survey revealed that the phytochemical and physicochemical investigation of root of $\mathrm{W}$. fruticosa has yet not been studied. On the basis of literature survey this plant selected to investigate its preliminary phytochemical and physicochemical properties. ${ }^{[7,8]}$

\section{MATERIALS AND METHODS}

\section{Collection and Identification}

The roots of $W$. fruticosa were collected from Barra village of district Janjgir-Champa (C.G.) in the month of November 2017 and the voucher sample of the plant authenticated by CSIR-NISCAIR, New Delhi, with voucher sample number NISCAIR/RHMD/Consult/2018/3207-08.

\section{Washing, Drying, and Grinding}

The root of $W$. fruticosa was collected and washed thoroughly with water to remove dust and sand and then dried under shade. The dried roots were ground into a coarse powder with the help of simple mechanical grinder and sieved with 10/44 mesh to get a coarse powder.

\section{Preparation of Plant Extract}

\section{Successive soxhlet extraction}

About $25 \mathrm{~g}$ of the air-dried powdered root was successively extracted with the petroleum ether, benzene, chloroform, acetone, ethanol, and water in a Soxhlet extractor. Each time before extracting with the next solvent, the powdered root has been dried at below $50^{\circ} \mathrm{C}$. The different extracts obtained were concentrated by distilling off the solvent and then evaporated to dryness on the water bath. The extracts obtained with each solvent were weighed, and percentage was calculated with reference to the weight of the air-dried root. The color and consistency of the extracts were noted. ${ }^{[5]}$ The nature 
and percentage yield of various extracts of $W$. fruticosa by successive solvent extraction is shown in Table 1.

\section{Direct Extraction Method}

For direct extraction method, $25 \mathrm{~g}$ of powdered root sample is extracted using Soxhlet extraction using ethanol as a solvent. The extract obtained was evaporated to remove excess solvent and dried on desiccators after drying measure extractive percentage yield and for further analysis.

\section{Phytochemical analysis of $W$. fruticosa root extract}

The various extracts which are obtained by successive solvent extraction of $W$. fruticosa roots such as petroleum ether extract, benzene extract, chloroform extract, acetone

Table 1: Nature and percentage yield of various extracts of Woodfordia fruticosa root

\begin{tabular}{llll} 
Extract & Colour & Consistency & Percentage yield \% w/w \\
\hline Successive solvent extract & & & \\
\hline Petroleum ether $\left(60-80^{\circ}\right)$ & Black & Sticky & 0.8 \\
Benzene & Dark brown red & Nonsticky & 0.68 \\
Chloroform & Dark Brown & Sticky & 0.95 \\
Acetone & Reddish Brown & Crystalline & 3.66 \\
Ethanol (95\%) & Reddish Brown & Crystalline & 6.61 \\
Water & Reddish & Crystalline & 1.62 \\
\hline Direct ethanolic extract & & & 11.6 \\
\hline Ethanol & Reddish Brown & Nonsticky & \\
\hline
\end{tabular}

Table 2: Qualitative chemical examination of various extracts

Test/Reagent used Successive solvent extracts

Direct extraction

\begin{tabular}{ccccccc}
\hline $\begin{array}{c}\text { Petroleum } \\
\text { ether extract }\end{array}$ & $\begin{array}{c}\text { Benzene } \\
\text { extract }\end{array}$ & $\begin{array}{c}\text { Chloroform } \\
\text { extract }\end{array}$ & $\begin{array}{c}\text { Acetone } \\
\text { extract }\end{array}$ & $\begin{array}{c}\text { Ethanol } \\
\text { extract }\end{array}$ & $\begin{array}{c}\text { Water } \\
\text { extract }\end{array}$ & $\begin{array}{c}\text { Ethanol } \\
\text { extract }\end{array}$
\end{tabular}

Alkaloids

Dragendorff's

Mayer's reagents

Amino acid and Proteins

Millon's reagent

Carbohydrates

Molisch's test

Fixed oil and fats

Saponification test

Flavonoids

Shinoda test

Glycosides

Borntrager's test

Legal's test

Gum and Mucilage

Molisch's test

Tannins (Phenolics)

Gelatin test

Steroids and triterpenoids

Salkowski test

Saponins

Foam test 
extract, ethanol, and aqueous extract were then subjected to qualitative tests for the identification of different types of phytoconstituent such as alkaloids, amino acids flavonoids, fixed oils, steroids, terpenoids, carbohydrates, gums and mucilage, tannins, polyphenols, and glycosides. ${ }^{[9]}$ Presence and absence of different phytoconstituents are shown in Table 2.

\section{Detection of Alkaloid}

A small portion of each extracts obtained after successive solvent extraction was subjected to few drops of dilute hydrochloric acid and filtered. Then, the extract was filtered and tested for alkaloid carefully with various alkaloidal reagents.

\section{Detection of Proteins}

Millon's test: $2 \mathrm{ml}$ of Millon's reagent was added to the test solution of different successive extract; white precipitate indicated the presence of amino acids.

\section{Detection of Carbohydrates}

Molisch's test: Alcoholic $\alpha$-naphthol was added to each successive extracts, and few drops of concentrated sulfuric acid added through sides of the test tube. Purple to violet color ring appeared at the junction.

\section{Detection of Fat and Fixed Oils}

Saponification test:Various extracts were treated with a small amount of $0.5 \mathrm{~N}$ alcoholic potassium hydroxide and a drop of phenolphthalein separately and heated on a water bath for 1-2 h. The formation of soap or partial neutralization of alkali indicated the presence of fixed oils and fats.

\section{Detection of for Steroids and Terpenoids}

Liebermann-Burchard test: To each successive extracts add $10 \mathrm{ml}$ of methanol and heated for about $30 \mathrm{~min}$. The mixture was filtered while hot, and a further $5 \mathrm{ml}$ of the solvent was added, heated and soluble materials were rinsed away. The solvent was evaporated off by rotary evaporator and triturate with ether in a test tube, and a few drops of Liebermann-Burchard reagent were added carefully. Blue-green ring between layers indicated the presence of steroids while pink, purple ring indicated the presence of terpenes.

\section{Detection of Flavonoids}

Shinoda test: In the extracts, few magnesium turnings and concentrated hydrochloric acid were added drop-wise, pink scarlet, crimson red or occasionally green to blue color appears after few minutes.

\section{Detection of Glycosides}

Borntrager's test: To $2 \mathrm{ml}$ of filtered hydrolysate, $3 \mathrm{ml}$ of chloroform was added and shaken, chloroform layer was separated and 10\% ammonia solution was added to its pink color indicated the presence of glycosides.

Legal's test: About $50 \mathrm{mg}$ of the different extracts were dissolved in pyridine; sodium nitroprusside solution was added and made alkaline using 10\% sodium hydroxide. Presence of glycoside was indicated by pink color.

\section{Detection of Gum and Mucilage}

Molisch's test: Few drops of alcoholic $\alpha$-naphthol solution were added to the extract, shaken the mixture and $1 \mathrm{ml}$ of concentrated sulfuric acid was added from the sides of the test tube well. A violet ring appears at the junction which indicates the presence of carbohydrates.

\section{Detection of Tannins (Phenolic Compounds)}

Gelatin test: Small amount of different successive extract was dissolved in $5 \mathrm{ml}$ of distilled water, and $2 \mathrm{ml}$ of $1 \%$ solution of gelatin containing $10 \%$ sodium chloride was added to the small amount of extract. White precipitates appear which indicates the presence of phenolic compounds.

\section{Detection of Steroids and Triterpenoids}

The extract was treated in chloroform with few drops of concentrated sulfuric acid; the mixture was shaken well and allowed to stand for some time, the red color appeared at the lower layer indicated the presence of steroids and formation of yellow color at lower layer indicated the presence of triterpenoids.

\section{Frothing Test for Saponins}

The extracts were transferred into a test tube, shaken vigorously, left to stand for $10 \mathrm{~min}$ and the result noted. A thick persistent froth indicated the presence of saponins.

\section{PHYSICOCHEMICAL DETERMINATION OF ROOT}

The air-dried coarsely powdered root of $W$. fruticosa (Linn.) Kurz was evaluated for its physicochemical parameters such as the ash values (total ash, water soluble ash, and acid insoluble ash), extractive values (water-soluble extractive value and 


\begin{tabular}{lccc} 
Table 3: Determination of Moisture contents of Woodfordia fruticosa root \\
$\begin{array}{l}\text { Initial weight of } \\
\text { Powder+China dish }\end{array}$ & $\begin{array}{c}\text { Final weight of } \\
\text { Powder+China dish }\end{array}$ & $\begin{array}{c}\text { Weight difference b/w } \\
\text { Initial and final weight }\end{array}$ & $\begin{array}{c}\text { Percentage of } \\
\text { moisture content (\%) }\end{array}$ \\
\hline $104.83 \mathrm{~g}$ & $104.61 \mathrm{~g}$ & $0.22 \mathrm{~g}$ & 4.4 \\
\hline
\end{tabular}

alcohol-soluble extractive values), and moisture content (loss on drying) according to the WHO guidelines. ${ }^{[10-12]}$

\section{DETERMINATION OF MOISTURE CONTENT}

An empty China dish was kept in a hot air oven for $30 \mathrm{~min}$ and then in desiccators for $30 \mathrm{~min}$ to ensure the moisture is completely removed from the evaporating dish, and it becomes completely moisture free. Weighed the empty China dish and tarred on weighing balance and then $2 \mathrm{~g}$ of W. fruticosa (Linn.) Kurz root powder was weighed in a tarred evaporating dish. Again weighed the evaporating dish containing powder and recorded the value as the weight of the powder drug with China dish before drying. The sample was dried in an oven at $105^{\circ} \mathrm{C}$ in a hot air oven for $30 \mathrm{~min}$. After $30 \mathrm{~min}$, it was placed in desiccators for cooling and weighed. The above procedure was carried out till weight reach a constant value. Moisture content is determined by subtracting the weight of empty China dish with constant value of China dish containing crude drug obtained after the drying. The experiment was repeated 3 times, and the result was calculated as a loss of weight in percent. The result is shown in Table 3.

\section{Determination of Alcohol-soluble Extractive Value}

About $5 \mathrm{~g}$ of $W$. fruticosa (Linn.) Kurz root powder was taken and macerated with $100 \mathrm{ml}$ of alcohol (95\%) in a closed flask for $24 \mathrm{~h}$. It was shaken frequently for the first $6 \mathrm{~h}$ and allowed to stand for $18 \mathrm{~h}$. The macerate was filtered rapidly taking precautions against loss of solvent. A reflux condenser was attached to the flask and boiled gently for $1 \mathrm{~h}$. The mixture was then filtered, $25 \mathrm{ml}$ of the filtrate transferred to a tarred Petri dish and evaporated to dryness over a waterbath. The Petri dish was then dried in an oven at $105^{\circ} \mathrm{C}$ for $6 \mathrm{~h}$, dried in desiccators (silica gel) for $30 \mathrm{~min}$ and weighed. The experiment was done in triplicate, and the content of extractable matter was then calculated in $\mathrm{mg}$ per gm with reference to air-dried material and expressed as a percentage. The result is shown in Table 4.

\section{Determination of Water-soluble Extractive Value}

About $5 \mathrm{~g}$ of the air-dried powder was taken and macerated with $100 \mathrm{ml}$ of distilled water in a closed flask for $24 \mathrm{~h}$. It was shaken frequently for the first $6 \mathrm{~h}$ and allowed to stand for the next $18 \mathrm{~h}$. The macerate was filtered rapidly; $25 \mathrm{ml}$ of

\begin{tabular}{|c|c|c|}
\hline $\begin{array}{l}\text { Solvent } \\
\text { used }\end{array}$ & $\begin{array}{l}\text { Quantity of dried } \\
\text { extract obtained (g) }\end{array}$ & $\begin{array}{l}\text { Extractive value } \\
\text { in Percentage (\%) }\end{array}$ \\
\hline Ethanol & 0.32 & 6.4 \\
\hline Water & 0.17 & 3.4 \\
\hline
\end{tabular}

\begin{tabular}{|c|c|c|}
\hline Ash value parameter & $\begin{array}{l}\text { Quantity } \\
\text { of ash (g) }\end{array}$ & $\begin{array}{c}\text { Percentage } \\
\text { of ash (\%) }\end{array}$ \\
\hline Total ash & 0.13 & 6.5 \\
\hline Acid-insoluble ash & 0.04 & 2 \\
\hline Water-soluble ash & 0.01 & 0.5 \\
\hline
\end{tabular}

this filtrate was evaporated to dryness in a tarred flat bottom shallow dish, and dried at $105^{\circ} \mathrm{C}$ for $6 \mathrm{~h}$, to constant weight and weighed. The percentage of water-soluble extractive value had been calculated with reference to the air-dried powder. The result is shown in Table 4.

\section{Ash Values Determination}

The quality of a drug can be determined by the ash left after ignition. There are different methods which measure the ash: Total ash, acid-insoluble ash, and water-soluble ash.

\section{Determination of Total Ash}

About $2 \mathrm{~g}$ of grounded root powder was accurately weighed and taken into a previously ignited and tarred crucible. The root powder was spread in an even layer in the crucible and ignited in a muffle furnace for about $6 \mathrm{~h}$ by gradually increasing the heat to $500-600^{\circ} \mathrm{C}$ until it was white indicating that it was free from carbon. The time taken for this process is about $6 \mathrm{~h}$. After complete ignition crucible was removed from the muffle furnace and cooled in desiccators and weighed. The content of total ash was calculated as mg per gm of air-dried material and expressed as a percentage. The experiment was carried out in triplicate. The average value of total ash is shown in Table 5.

\section{Determination of Acid-insoluble Ash}

About $25 \mathrm{ml}$ of dilute hydrochloric acid was added to the crucible for dissolving the total ash obtained from the above procedure and covered with a watch glass. It was boiled gently 
for $5 \mathrm{~min}$. The watch glass was rinsed with $5 \mathrm{ml}$ of hot water, and the liquid was added to the crucible. The insoluble matter was collected on an ashless filter paper and washed with hot water until the filtrate was neutral. The filter paper containing the insoluble matter was transferred to the crucible, dried on a hot plate, and ignited to a constant weight. The crucible was cooled in desiccators and weighed. The content of acid-insoluble ash was calculated in mg per gm of air-dried material and expressed as a percentage. The experiment was carried out in triplicate. The content of acid-insoluble ash was calculated as a percentage of ash with reference to the air-dried root powder. The result showed in Table 5.

\section{Determination of Water-soluble Ash}

The total ash was boiled with $25 \mathrm{ml}$ of water for $5 \mathrm{~min}$. The insoluble matter was collected on an ashless filter paper, and then the residue was washed with hot distilled water and ignited for $15 \mathrm{~min}$ at a temperature not exceeding $450^{\circ} \mathrm{C}$. The total weight of insoluble matter was subtracted from the weight of the total ash. Their difference in weights represented the water-soluble ash. The percentage of watersoluble ash should be calculated with reference to the airdried root powder. The experiment was carried in triplicate. The result showed in Table 5.

\section{RESULTS AND DISCUSSION}

Adulteration is one of the major problems due to the absence of standards of the proper identification and quality control of the drug. Skill hand and cost factors for pharmaceuticals purposes, the quality of medicine must be as high as that of other medicinal preparations. Quality refers to the intrinsic value of the drug, the number of medicinal principles or active constituents present. This study of phytochemical and physicochemical investigation of $W$. fruticosa root revealed a set of parameters which may enable those who handle this plant to maintain its quality control.

\section{Physicochemical Investigation}

The study of physicochemical parameters is useful to determine the physiological and nonphysiological adulteration. Determination of physical constant of any drug is important for the detection of adulteration and improper storage or handling. The moisture content of the drug will help to determine the possibility of microbial growth. ${ }^{[13]}$ In root very less amount of moisture was present; it was only $4.4 \%(\mathrm{w} / \mathrm{w})$. The total ash value indicates the level of mineral in the drug. The insoluble ash value gives the idea about adulteration of the drug with the siliceous element. ${ }^{[14]}$ The result of total ash value found in the root was $6.5 \%(\mathrm{w} / \mathrm{w})$. The results acid insoluble ash value and water soluble ash value were $2 \%$ and $0.5 \%$. Alcohol soluble and water-soluble extractive value was $6.4 \%(\mathrm{w} / \mathrm{v})$ and $3.4 \%(\mathrm{w} / \mathrm{v})$. The values obtained after the physical evaluation of the crude drug or powdered crude drug such as loss on drying, ash values, and extractive values serve as standard data shown in Table 1 for the identification and quality control of this plant for future study. ${ }^{[13,14]}$

\section{Phytochemical Screening}

The preliminary qualitative test is useful in the detection of bioactive principles and subsequently may lead to drug discovery and development. The phytochemicals found in the different extracts were tannin, glycoside, phytosterol, fixed oil and fat, carbohydrate, saponin, and gums. Detail results of qualitative phytochemical screening shown in Table 2.

\section{CONCLUSION}

$W$. fruticosa plant was collected, and herbarium of the plant was prepared and authenticated. The collected root was dried and ground and performed the successive solvent extraction. The phytochemical analysis of different successive extract was performed. The successive solvent extract of the root of $W$. fruticosa represents that ethanol is a suitable solvent for the extraction of the majority of constituents. In the ethanol highest extract has been obtained $6.61 \%$ compared to the other solvents they are, respectively, acetone $3.66 \%$, water $1.62 \%$, chloroform $0.95 \%$, petroleum ether $0.8 \%$, and benzene $0.68 \%$. Various physicochemical parameters were also determined such as that moisture content, extraction value (alcohol and water-soluble extractive value), and ash value (total ash value, acid-insoluble ash value, and water-soluble ash value). The different physicochemical parameters are also showing good results. These physical parameters will help to identify the authenticity of the drug. In the conclusion, it will serve as standard data for the quality control of the preparation containing this plant in future and also helpful in distinction from other allied species and adulterants. A preliminary screening test may be useful in the detection of bioactive principle having therapeutic properties. Their further studies are recommended to isolate and characterize the chemical constituents which may be responsible for the pharmacological activities of the $W$. fruticosa root. These work findings may help all researchers, pharmacological investigators and dosage form formulators and pharmaceutical scientists to develop a new way in the field of health science.

\section{ACKNOWLEDGMENTS}

Authors are pleased to acknowledge Siddhi Vinayaka Institute of Technology and Sciences, Bilaspur, Chhattisgarh, India, for providing the necessary facilities to carry out this research work. 


\section{REFERENCES}

1. Lay JS, Hooi KB, Amirin S, Mohd ZA. Preliminary phytochemical and physicochemical characterization of Gymnema sylvestre (lour) merr (compositae) Leaf. Trop J Pharm Res 2013;12:777-82.

2. Jalal UB, Quadsia N, Shabir P, Mohammad A, Aisha S, Nazeem F, et al. Pharmacognostical and phytochemical evaluation of Melissa parviflora and HPTLC fingerprinting of its extracts. Sch Res Libr J Natl Prod Plant Resour 2013;3:1-10.

3. Ameh SJ, Obodozie OO, Inyang US, Abubakar MS, Garba M. Quality control tests on andrographis Paniculata nees (Family: Acanthaceae)-an Indian 'wonder' plant grown in Nigeria. Trop J Pharm Res 2010;9:387-94.

4. Kumar D, Sharma M, Sorout A, Soroha K, Verma S. Wood fruticosa kurz: A review of its botany, chemistry and biological activities. J Pharm Phytochemistry 2016;5:293-8.

5. Meena R, Neha G, Vidya P. Physiochemical evaluation, phytochemical screening and chromatographic fingerprint profile of Woodfordia fruticosa (L.) kurz extracts. Int J Pharm Sci Res 2014;5:2772-82.

6. Das PK, Goswami S, Chinniah A, Panda N, Banerjee S, Sahu NP, et al. Woodfordia fruticosa: Traditional uses and recent findings. J Ethnopharmacology 2007;110:189-99.

7. Kirtikar KR, Basu BD, Basu LM, Indian Medicinal Plant Part 1-3. Allahabad (India): Bishan Singh Mahendra Agency; 1935.
8. Pullaiah T. Biodiversity in India. Vol. 4. New Delhi: Regency Publication; 2006. p. 543.

9. Onwukaeme DN, Ikuegbvweha TB, Asonye CC. Evaluation of phytochemical constituents, antibacterial activities, and effect of exudate of Pycanthus angolensis weld warb (Myristicaceae) on corneal ulcers in rabbits. Trop J Pharm Res 2007;6:725-30.

10. World Health Organization. Quality Control Methods for Medicinal Plants Materials. Geneva: World Health Organization; 1998. p. 1-15.

11. Bandaranayake WM, Ahmad I, Owais AM. Quality control, screening, toxicity and regulations of herbal drugs. In: Modern Phytomedicine: Turning Medicinal Plants into Drugs. Germany: Wiley-VCH Verlag Gmbh and Co.; 2006. p. 25-57.

12. Syed YH, Khan M, Bhuvaneshwari J, Ansari JA. Phytochemical investigation and standardization of extracts of flowers of Wood fordia a preliminary study. J Pharm Biosci 2013;4:134-40.

13. Thomas S, Patil DA, Patil AG, Chandra N. Pharmacognostic evaluation and physicochemical analysis of Averrhoa carambola L fruit. J Herbal Med Toxicol 2008;2:51-4.

14. Vaghasiya Y, Nair R, Chanda S. Antibacterial and preliminary phytochemical and physico-chemical analysis of Eucalyptus citriodora Hk leaf. Nat Prod Res 2008;22:754-62.

Source of Support: Nil. Conflict of Interest: None declared. 